\title{
MENINGKATKAN KEMAMPUAN BERPIKIR KREATIF MATEMATIS MELALUI PEMBELAJARAN BERBASIS MASALAH BERBANTUAN SOFTWARE MATLAB
}

\author{
Yusef Aprilian Saefulloh ${ }^{1}$, Yoni Sunaryo², Nur Eva Zakiah ${ }^{3}$ \\ 1,2,3 Program Studi Pendidikan Matematika, Universitas Galuh, Jl. R. E. Martadinata No.150, Ciamis, Indonesia \\ Email: yusefaprilian1@gmail.com
}

\begin{abstract}
This research is research that aims to improve mathematical creative thinking skills through problem-based learning assisted by Matlab software on matrix material. The research method is a quasi-experimental method with a pretestposttest group design, with sampling using a saturated sampling technique. The results showed that learning using a problem-based learning approach assisted by Matlab software was better than the control class. the results of this study showed that the experimental class with problem-based learning assisted by Matlab software obtained an average $\mathrm{N}$-gain value of 0.49 . This means that problem-based learning assisted by Matlab software can improve creative thinking skills in the medium category. The control class with problem-based learning obtained an average $\mathrm{N}$-gain value of 0.24 . This means that problem-based learning can improve creative thinking skills with low categories.
\end{abstract}

Keywords: Problem Based Learning, Creative Thinking Ability, Matlab Software, Matrix.

\begin{abstract}
ABSTRAK
Penelitian ini merupakan penelitian yang bertujuan untuk meningkatkan kemampuan berpikir kreatif matematis melalui pembelajaran berbasis masalah berbantuan software matlab pada materi matriks. Adapun metode penelitian yakni metode kuasi eksperimen dengan desain kelompok pretest-postest, dengan pengambilan sampel dengan menggunakan teknik sampling jenuh. Hasil penelitian menunjukan bahwa pembelajaran yang menggunakan pendekatan pembelajaran berbasis masalah berbantuan software matlab lebih baik dari pada kelas kontrol. Hasil penelitian ini menunjukan bahwa kelas eksperimen dengan pembelajaran berbasis masalah berbantuan software matlab memperoleh nilai rata-rata $\mathrm{N}$ gain 0,49. Artinya pembelajaran berbasis masalah berbantuan software matlab dapat meningkatkan kemampuan berpikirr kreatif dengan kategori sedang. Kelas kontrol dengan pembelajaran berbasis masalah memperoleh nilai ratarata $\mathrm{N}$-gain 0,24 . Artinya pembelajaran berbasis masalah dapat meningkatkan kemampuan berpikir kreatif dengan kategori rendah.
\end{abstract}

Kata Kunci: Pembelajaran Berbasis Masalah, Kemampuan Berpikir Kreatif, Software Matlab, Matriks.

Cara sitasi: Saefulloh, Y. A., Sunaryo, Y., \& Zakiah, N.E. (2021). Meningkatkan Kemampuan Berpikir Kreatif Matematis Melalui Pembelajaran Berbasis Masalah Berbantuan Software Matlab. J-KIP (Jurnal Keguruan dan IImu Pendidikan),2(3),95-102. 


\section{PENDAHULUAN}

Pendidikan merupakan sarana terpenting untuk mewujudkan kemajuan bangsa dan negara, hal ini lantaran pendidikan merupakan proses budaya yang bertujuan untuk menaikkan harkat dan martabat manusia. Dengan mewujudkan pendidikan, pendidik harus mempunyai terobosan yang bisa membawa peserta didik menjadi yang lebih baik. Oleh karenanya guru bertanggung jawab terhadap perkembangan peserta didiknya dengan upaya mengembangkan semua potensi (Hidayati, 2017). Dalam Undang-undang Republik Indonesia No 20 tahun 2003 tentang Sistem Pendidikan Nasional Bab I pasal 1 dinyatakan bahwa Pendidikan merupakan usaha sadar dan terencana untuk mewujudkan suasana belajar dan proses pembelajaran agar peserta didik secara aktif mengembangkan potensi dirinya untuk memiliki kekuatan spiritual, keagamaan, pengenalan diri, kepribadian, kecerdasan, akhlak mulia, serta keterampilan yang diperlukan dirinya, masyarakat, bangsa dan negara (Depdiknas, 2003). Artinya pendidikan di sekolah merupkan proses yang terpola dan mempunyai tujuan, sehingga segala sesuatu yang dilakukan oleh pendidik dan peserta didik bisa mencapai tujuan pembelajaran. Melalui proses pendidikan yang terjadwal diarahkan buat menciptkan suasana belajar yang kondusif serta proses belajar yang menyenangkan, dengan tujuan peserta didik bisa mengembangkan potensi diri.

Salah satu pengembangan potensi peserta didik yaitu kemampuan berpikir kreatif pada matematika juga terdapat pada Kurikulum 2013. Hal ini terbukti dengan adanya Peraturan Pemerintah Nomor 17 Tahun 2010 dalam Kurikulum 2013 tentang Pengelolaan dan Penyelenggaraan Pendidikan, yang menyebutkan bahwa tujuan penyelenggaraan pendidikan dasar dan menengah yaitu membangun landasan bagi berkembangnya potensi peserta didik agar menjadi manusia yang berilmu, cakap, kritis, kreatif, dan inovatif.

Secara umum pendidikan bertujuan untuk mengembangkan seluruh potensi yang utuh dan handal, serta kini adanya teknologi membantu untuk menaikkan potensi yang dimiliki peserta didik (Sudarsana, 2018). Melalui pembelajaran berbasis masalah pula bisa memicu kemampuan berpikir kreatif matematis, pembelajaran berbasis masalah ini pembelajaran yang berpusat pada peserta didik yang mengorganisasikan kurikulum dan pembelajaran pada situasi yang tidak terstruktur dan berupa masalah dunia nyata (Amalia et al., 2020; Nugraha \& Mahmudi, 2015). Dalam Pembelajaran berbasis masalah ini adanya acuan belajar peserta didik yang memakai masalah menjadi pemandu dan pemicu proses belajar peserta didik, dengan diawali penyajian masalah pada peserta didik untuk mendorong menciptakan sendiri pengetahuannya, dan membuat peserta didik benar-benar berpikir untuk mencari solusi menurut masalah yang diberikan.

Kemampuan berpikir kreatif adalah suatu tuntutan untuk mampu meciptakan suatu ide atau cara lain dalam penyelesaian masalah sebagai upaya untuk menyelesaikan masalah yang terjadi pada kehidupan sehari-hari. Kemampuan berpikir kreatif matematika berarti dapat dikatakan menjadi upaya seorang peserta didik untuk mampu menemukan solusi melalui ide/gagasan dalam penyelesaian atau pemecahan masalah yang terkait dengan matematika (Amalia et al., 2020; Faelasofi, 2017).

Pada kelas XI SMA Plus Darussalam Ciamis ditemukan permasalahan-permasalahan yang dihadapi peserta didik. Permasalahan tersebut diantaranya : 1) peserta didik cenderung tidak menjawab pada saat pendidik memberikan pertanyaan, sebagai akibatnya hal tersebut belum memperlihatkan kelancaran peserta didik dalam mengemukakan gagasannya, 2) saat menjawab soal/permasalahan, peserta didik hanya memberikan jawaban yang sesuai dengan apa yang dicontohkan pendidik 3) peserta didik cenderung masih menghafalkan atau meniru apa yang diberikan oleh guru, sebagai akibatnya hal tersebut peserta didik belum tampak berpikir orisinil dalam menuntaskan suatu masalah, 4) peserta didik belum mampu mengungkapkan secara rinci maupun runtut berdasarkan suatu masalah yang diberikan oleh guru, sehingga keterampilan mengelaborasi peserta didik belum tampak dalam memecahakan suatu masalah. Kemampuan peserta didik saat mencari cara lain jawaban dari permasalahan masih kurang, sehingga belum tampak keluwesan peserta didik memikirkan alternatif jawaban yang bervariasi. Dari 
permasalahan tersebut peneliti menduga bahwa kemampuan berpikir kreatif peserta didik dalam pembelajaran matematika masih rendah.

Media pembelajaran yang berbasis teknologi dan informasi ini diharapkan sanggup memecahkan kesulitan yang dialami peserta didik dan memberikan kemudahan bagi pendidik dan peserta didik pada saat pembelajaran matematika (Adnyani et al., 2018). Dalam pemanfaatan teknologi ini merupakan cara untuk meningkatkan kemampuan berpikir kreatif. Hal tersebut menandakan bahwa berpikir kreatif bisa mengembangkan daya pikir yang mencakup wawasan dengan unsur-unsur yang luas dan kemampuan berpikir kreatif matematis merupakan kemampuan menemukan solusi bervariasi yang bersifat baru terhadap masalah matematika yang bersifat terbuka secara mudah dan fleksibel, tetapi bisa diterima kebenarannya (Amidi \& Zahid, 2016). Salah satu teknologi pembelajaran yang dapat digunakan untuk meningkatkan memampuan berpikir kreatif matematis dengan menggunkan software MATLAB (Matriks Laboratory) yang memungkinkan peserta didik dapat mengeksplorasi berbagai macam cara untuk menyelesaikan permasalahan.

Berdasarkan hasil observasi saat pembelajaran pada materi matriks peserta didik dalam memecahkan masalah terkait materi matriks masih rendah dengan berdasarkan indikator berpikir kreatif rendah. Serta disebabkan oleh materi matriks yang abstrak dan kurang masuk dalam benak peserta didik. Sehingga perlu adanya pembelajaran yang menggunakan permasalahan sehari-hari, karena konsep matriks dapat dibelajarkan dari masalah sehari-hari dan diaplikasikan pada software matlab.

Selain pembelajaran berbasis masalah memiliki kelebihan, diantaranya (1) Peserta didik lebih memahami konsep yang diajarakan sebab peserta didik sendiri yang menentukan konsep masalah; (2) Peserta didik secara aktif terlibat dalam proses pemecahan masalah yang menuntut kemampuan berpikir yang lebih tinggi seperti kemampuan berpikir kreatif ; (3) Pengetahuan yang didapatkan peserta didik lebih bermakna dan tertanam berdasarkan skemata yang dimiliki peserta didik, terdapat hal yang dianggap penting sebagai penunjang proses pembelajaran, yaitu penggunaan media software matlab pada peserta didik.

Matlab merupakan bahasa pemrograman level tinggi yang dikhususkan untuk teknik komputasi. Matlab mengintegrasikan kemampuan untuk komputasi, visualisasi data dan pemrograman dalam sebuah lingkungan yang interaktif dan mudah digunakan. Melalui bantuan software Matlab ini diharapkan bisa memberikan kesempatan pada peserta didik untuk memakai daya pikir, mengembangkan ide, menemukan solusi suatu masalah yang mungkin mereka kembangkan sendiri dan mengemukakan pendapatnya. Oleh karena itu, dengan menggunakan pembelajaran berbasis masalah berbantuan software Matlab ini diharapkan kemampuan berpikir kreatif dalam pemecahan masalah peserta didik bisa tumbuh dan berkembang.

Penelitian yang akan dilaksanakan di kampus SMA Plus Darussalam Ciamis ini berdasarkan penemuan ketika melakukan observasi, tujuan penelitian ini yaitu peneliti ingin mengetahui apakah peningkatan kemampuan berpikir kreatif matematis peserta didik menggunakan pembelajaran berbasis masalah berbantuan software matlab lebih baik dari kelas kontrol, serta diharapkan hasil penelitian ini menjadi referensi mengenai meningkatkan kemampuan berpikir kreatif matematis.

\section{METODE PENELITIAN}

Desain penelitian yang digunakan dalam penelitian ini adalah desain kelompok pretespostes (pretes-postes control group design). Populasi dalam penelitian ini adalah seluruh peserta didik SMA Plus Darusslam Ciamis. Sedangkan sampel penelitian ini dipilih menggunakan Teknik Non-Probabilitas (sampling jenuh) atau pengumpulan sample bila semua anggota populasi dijadikan sample. Alasannya, yaitu pada kelas XI hanya terdapat 2 kelas. Maka yang menjadi sampling dalam penelitian ini kelas XI IPA sebanyak 12 orang dan kelas XI IPS sebanyak 7 orang dengan jumlah total keseluruhannya sebanyak 19 peserta didik sebagai sampel. Untuk selanjutnya kelas XI IPA disebut kelas eksperimen dan kelas XI IPS desebut kelas kontrol.

Dalam penelitian ini terdapat hipotesis untuk penelitian ini adalah: 
$\mathrm{H}_{0}=\mu_{1} \leq \mu_{2}$ : Peningkatan kemampuan berpikir kreatif matematis peserta didik yang menggunakan pembelajaran berbasis masalah berbantuan software matlab tidak lebih baik dari pada kelas kontrol.

$\mathrm{H}_{1}=\mu_{1}>\mu_{2}$ : Peningkatan kemampuan berpikir kreatif matematis peserta didik yang menggunakan pembelajaran berbasis masalah berbantuan software matlab lebih baik dari pada kelas kontrol.

\section{HASIL DAN PEMBAHASAN}

Tahap awal pada penelitian ini, peneliti harus menyiapkan instrumen yang akan diujikan kepada kedua kelas serta menyiapkan software matlab untuk kelas eksperimen. Instrumen diberikan kepada peserta didik yang pernah mendapatkan materi matriks pada sekolah yang sama. Kemudian hasil uji coba instrumen tersebut diuji mengunakan software anates v.4 dengan melihat hasil validitas, reabilitas, tingkat kesukaran dan saya beda soal sehingga diperoleh instrumen yang benarbenar sesuai untuk mengukur kemampuan berpikir kreatif matematis peserta didik kelas XI. Setelah soal diketahui hasil analisisnya maka soal instrumen tersebut dapat diberikan kepada peserta didik kelas eksperimen dan kelas kontrol untuk mengetahui kemampuan awal kedua kelas, baik kelas eksperimen maupun kelas kontrol apakah sama atau tidak. Oleh karena itu penelitian ini menggunakan pretest pada kelas eksperimen dan kontrol. Rata-rata awal dari kelas eksperimen adalah 8,2 dan kelas kontrol adalah 8,4.

Berdasarkan data nilai pretest, uji normalitas dengan menggunakan software SPSS dengan hasil kelas eksperimen diperoleh nilai signifikan 0,200 dan untuk kelas kontrol diperoleh nilai signifikasi 0,106 . Hasil tersebut kemudian dikonsultasikan dengan kriteria uji signifikasi apabila $\geq$ 0,05 dinyatakan data berdistribusi normal dan $<0,05$ dinyatakan data berdistribusi tidak normal karena nilai signifikasi kelas eksperimen dan kelas kontrol lebih dari 0,05 maka kedua kelas berdistribusi normal.

Uji homogenitas pretest dilakukan menggunkan software SPSS untuk mengetahui apakah antra kelas eksperimen dan kelas kontrol berdistribusi homogen. Berdasarkan hasil yang didapat dari perhitungan analisis diperoleh nilai signifikasi 0,585. Hasil tersebut kemudian dikonsultasikan dengan kriteria uji signifikasi apabila $\geq 0,05$ dinyatakan varians data homogen dan $<0,05$ dinyatakan varians data tidak homogen. Dikarenakan nilai signifikansi lebih dari 0,05 maka kedua kelas homogen.

Selanjutnya untuk mengetahui perbedaan rata-rata pretest dari kedua kelas maka digunakan analisis data menggunakan uji-t dengan bantuan software SPSS, dari analisis tersebut diperoleh signifikasi (2-tailed) sebesar 0,740 kemudian dikonsultasikan dengan kriteria uji signifikasi apabila $\geq 0,05$ dinyatakan tidak ada perbedaan kemampuan bepikir kreatif dan $<0,05$ dinyatakan ada perbedaan kemampuan berpikir kreatif matematis. Dikarenakan nilai signifikasi lebih dari 0,05 maka tidak ada perbedaan kemampuan berpikir kreatif matematis.

Setelah diketahui normalitas, homogenitas dan uji perbedaan rata-rata dari hasil pretest kedua kelompok, langkah selanjutnya peneliti memberikan perlakuan pada kelas eksperimen dengan menggunakan metode eksperimen dengan pembelajaran berbasis masalah berbantuan software matlab dan pembelajaran berbasis masalah pada kelas kontrol.

Untuk mengetahui seberapa besar perbedaan tersebut selanjutnya dilakukan uji N-gain, hasil perhitungan dengan menggunakan software SPSS untuk kelas eksperimen (XI IPA) diperoleh rata-rata pretest 8,2 dan rata-rata posttest 11,9 sehingga diperoleh rata-rata gain sebesar 0,49 . Artinya kelas eksperimen (XI IPA) mengalami peningkatan kemampuan berpikir kreatif matematis dengan kategori sedang karena $0,3 \leq \mathrm{g} \leq 0,7$. Pada kelas kontrol (XI IPS) diperoleh rata-rata pretest 8,4 dan rata-rata posttest 10,3 sehingga diperoleh rata-rata gain sebesar 0,24 . Artinya kelas kontrol (XI IPS) juga mengalami peningkatan kemampuan berpikir kreatif matematis, namun peningkatannya dalam kategori rendah karena $g<0,3$. Berdasarkan data tersebut, maka dikatakan peningkatan kemampuan berpikir kreatif dengan pembelajaran berbasis masalah berbantuan 
software matlab lebih baik dibandingkan kelas kontrol yang menggunkan model pembelajaran berbasis masalah.

Adapun proses pembelajaran yang peneliti lakukan pada kelas eksperimen dan control adalah kelas eksperimen dengan menggunakan metode pembelajaran berbasis masalah berbantuan software matlab, sedangkan kelas kontrol menggunkan metode pembelajaran berbasis masalah tanpa berbantuan software matlab. Kelas XI IPA sebagai kelas eksperimen, diberikan perlakuan dengan menggunakan metode eksperiment dengan pembelajaran berbasis masalah berbantuan software matlab dalam materi matriks. Guru menjelaskan materi matriks dengan melakukan eksperimen melalui pembelajaran berbasis masalah berbantuan software matlab, yaitu mengamati, menanya, mengekperimen, mengasosiasi serta mengkomunikasikan. Adapun rincian proses pembelajaran kelas eksperimen sebagai berikut:

1. Pertemuan pertama, proses pembelajaran pada kelas eksperimen yaitu mempelajari pengertian matriks terdiri dari macam-macam matriks, kesamaan matriks, dan transpose matriks. Pembelajaran diawali dengan guru memberikan suatu permasalahan dalam bentuk konteks kehidupan sehari-hari, selanjutnya guru meminta siswa untuk berkelompok dengan teman sebangkunya dan membagikan lembar kerja siswa dan mengisi lembar kerja siswa yang sudah diberikan guru, serta guru mendorong atau membimbing siswa untuk mengumpulkan data dan melakukan percobaan dengan mengacu pada lembar kerja siswa dan software matlab yang diberikan dengan siswa mengoperasikan matlabnya untuk mencari hasil dari permaslahan yang diberikan, kemudian guru meminta beberapa kelompok untuk mempersentasikan hasil yang diperoleh di lembar kerja siswa dengan memberikan penjelasan dari argumen-argumennya, Langkah terakhir guru dan siswa menyimpulkan hasil pembelajaran yang telah dilakukan dengan mengacu pada lembar kerja siswa.

2. Pertemuan kedua, proses pembelajaran pada kelas eksperimen yaitu mempelajari operasi matriks terdiri dari penjumlahan matriks, pengurangan matriks, perkalian matriks dengan skalar, perkalian matriks dengan matriks. Pembelajaran diawali dengan guru memberikan contoh soal dalam bentuk konteks, dengan soal agar mengenal operasi pada matriks terkait dengan penjumlahan, pengurangan maupun perkalian pada matriks, selanjutnya guru meminta siswa untuk berkelompok dan memberikan lembar kerja siswa dan mengisi lembar kerja siswa yang sudah diberikan guru, serta guru membantu dan mengamati interaksi yang terjadi dalam kegiatan pembelajaran yang berlangsung terutama kegiatan berkelompok yang telah dilakukan dalam menyelesaikan permasalahan dengan berbantuan software matlab siswa mengoperasikan matlabnya untuk mencari hasil dari permaslahan yang diberikan, selanjutnya guru meminta untuk mengumpulkan data dan melakukan percobaan dengan mengacu pada lembar kerja siswa dan software matlab yang diberikan, kemudian guru meminta beberapa kelompok untuk mempersentasikan hasil yang diperoleh di lembar kerja siswa dengan memberikan penjelasan dari argumen-argumennya. Langkah terakhir guru dan siswa membahas secara bersama-sama dan menyimpulkan hasil pembelajaran yang telah dilakukan dengan mengacu pada lembar kerja siswa.

Adapun siswa kelas XI IPS sebagai kelas kontrol di berikan pembelajaran berbasis masalah. Pembelajaran pada kelas kontrol menggunkan metode pembelajaran berbasis masalah. Guru memberikan lembar kerja siswa, siswa menyelesaikan lembar kerja siswa dan mendiskusiskan serta mengerjakan soal dari guru.

1. Pertemuan Pertama, proses pembelajaran pada kelas kontrol yaitu mempelajari pengertian matriks yang terdiri dari jenis-jenis matriks, kesamaan matriks, transpose matriks. Langkah pertama yaitu orientasi siswa dengan guru membarikan suatu permasalahan dalam konteks kehidupan sehari-hari, guru meminta siswa untuk berkelompok dengan teman sebangkunya dan membagikan lembar kerja siswa kepada setiap kelompok, kemudian guru mendorong dan meminta siswa untuk mengumpulkan data dan melakukan percobaan dengan mengacu pada lembar kerja siswa, selanjutnya guru meminta beberapa kelompok untuk mempersentasikan 
hasil yang diperoleh di lembar kerja siswa dengan memberikan penjelasan dari argumenargumennya. Langkah terakhir guru dan siswa menyimpulkan hasil pembelajaran yang telah dilakukan dengan mengacu pada lembar kerja siswa.

2. Pertemuan kedua, proses pembelajaran pada kelas kontrol yaitu mempelajari operasi pada matriks yang terdiri dari penjumlahan matriks, pengurangan matriks, perkalian matriks dengan skalar, perkalian matriks dengan matriks. Langkah pertama yaitu orientasi siswa dengan guru memberikan contoh soal dalam bentuk konteks, dengan soal agar mengenal operasi pada matriks terkait dengan penjumlahan, pengurangan, maupun perkalian matriks, selanjutnya guru meminta siswa belajar secara berkelompok dan guru memberikan lembar kerja siswa kepada setiap kelompok, guru membantu dan mengamati interaksi yang terjadi dalamkegiatan pembelajaran yang berlangsung terutama kegiatan berkelompok yang telah dilakukan dalam menyelesaikan permasalahan, kemudian guru meminta mengumpulkan seluruh pengerjaan siswa secara berkelompok dan meminta beberapa kelompok untuk mempersentasikan hasil pengerjaan lembar kerja siswa, langkah terakhir guru dan siswa membahas secara bersamasama dan menyimpulkan hasil pembelajaran yang telah dilakukan.

\section{KESIMPULAN}

Berdasarkan hasil dan pembahasan penelitian, peneliti memperoleh kesimpulan yang dapat diambil dari penelitian mengenai peningkatan kemampuan berpikir kreatif matematis melalui pembelajaran berbasis masalah berbantuan software matlab pada materi matriks di SMA Plus Darussalam Ciamis yaitu, pembelajaran yang menggunakan pendekatan pembelajaran berbasis masalah berbantuan software matlab lebih baik dari pada kelas kontrol. dengan hasil penelitian ini menunjukan bahwa kelas eksperimen dengan pembelajaran berbasis masalah berbantuan software matlab memperoleh nilai rata-rata $\mathrm{N}$-gain 0,49 . Artinya pembelajaran berbasis masalah berbantuan software matlab dapat meningkatkan kemampuan berpikirr kreatif dengan kategori sedang. Kelas kontrol dengan pembelajaran berbasis masalah memperoleh nilai rata-rata $\mathrm{N}$-gain 0,24 . Artinya pembelajaran berbasis masalah dapat meningkatkan kemampuan berpikir kreatif dengan kategori rendah.

\section{REKOMENDASI}

Serta saran bagi peneliti selanjutnya yang ingin melakukan penelitian tentang meningkatkan kemampuan berpikir kreatif matematis adalah:

1. Peneliti selanjutnya perlu mengkaji lebih banyak sumber maupun referensi yang terkait dengan metode pembelajaran yang cocok dengan materi yang ingin disampaikan, Sehingga hasil penelitiannya dapat lebih baik.

2. Peneliti selanjutnya diharapkan lebih mempersiapkan diri dalam proses pengambilan serta pengumpulan data dan segala sesuatunya sehingga penelitian dapat dilaksanakan lebih baik.

\section{UCAPAN TERIMAKASIH}

Penulis mengucapkan terima kasih kepada Fakultas Keguruan dan IImu Pendidikan Universitas Galuh Ciamis, seluruh dosen Program Studi Pendidikan Matematika terutama ibu Yoni Sunaryo, M.Pd dan Ibu Nur Eva Zakiah,S.Pd.M.Pd selaku dosen pembimbing yang telah memberikan arahan-arahan kepada penulis sehingga tersusunnya artikel ini.

\section{DAFTAR PUSTAKA}

Adnyani, L. P. W., Auliya, R. N., \& Pinahayu, E. A. R. (2018). Matlab Application In Development Mathematical Learning In Senior High School. UNES Journal of Community Service, 3(2), 162 165.

Amalia, M., Ilmiyati, N., \& Dan, A. R. (2020). Pengaruh Penerapan Model Pembelajaran Berbasis 
Masalah Terhadap Keterampilan Berpikir Kritis Siswa MTs. J-KIP (Jurnal Keguruan dan IImu Pendidikan), 1 (1), 32-41. https://ojs.unigal.ac.id/index.php/jkip/article/view/2297

Amalia, T., Toto, T., \& Yulisma, L. (2020). Pengaruh Model Problem Based Learning Berbasis Stem Terhadap Kemampuan Berpikir Kreatif Dan Motivasi Belajar Siswa. J-KIP (Jurnal Keguruan dan IImu Pendidikan), 1(1), 20-31. https://ojs.unigal.ac.id/index.php/jkip/article/view/2298

Amidi, \& Zahid, M. Z. (2016). Membangun Kemampuan Berpikir Kreatif Matematis Dengan Model Pembelajaran Berbasis Masalah Berbantuan E-Learning. Seminar Nasional Matematika $X$ Universitas Negeri Semarang 2016, 586-594.

Depdiknas. (2003). Undang-undang republik Indoneseia nomor 20 tahun 2003 (Vol. 71). https://doi.org/10.1111/j.1651-2227.1982.tb08455.

Faelasofi, R. (2017). Identifikasi Kemampuan Berpikir Kreatif Matematika Pokok Bahasan Peluang. JURNAL E-DuMath, 3(2), 155-163. https://doi.org/10.26638/je.460.2064

Hidayati, A. U. (2017). Melatih Keterampilan Berfikir Tingkat Tinggi Dalam Pembelajran Matematika Pada Siswa Sekolah Dasar. Pendidikan Dan Pebelajaran Dasar, 4(20), 143-156.

Nugraha, T. S., \& Mahmudi, A. (2015). Keefektifan Pembelajaran Berbasis Masalah Dan Problem Posing Ditinjau Dari Kemampuan Berpikir Logis Dan Kritis. Jurnal Riset Pendidikan Matematika, 2(1), 107. https://doi.org/10.21831/jrpm.v2i1.7154

Sudarsana, I. K. H. D. N. D. (2018). Optimalisasi Penggunaan Teknologi Dalam Implementasi Kurikulum Di Sekolah (Persepektif Teori Konstruktivisme). Cetta: Jurnal IImu Pendidikan, 8-15. http://library1.nida.ac.th/termpaper6/sd/2554/19755.pdf 
